\title{
Ho Chi Minh Thoughts On The Relationship Between Economic Development, Culture And People
}

\begin{abstract}
Master. Nguyen Duy Thanh
Abstract

Creatively applying Ho Chi Minh's thought and our Party's view on the dialectical relationship between economic development and culture, it is necessary to thoroughly grasp and better implement the orientation of harmonious combination between economic development and cultural development. economic and cultural development, building people, realizing social progress and justice right in each step and each development policy. To do so, each economic policy must aim at cultural and human development, progress and social justice; Every cultural policy, people building, every implementation of social progress and justice must contribute to economic development. Any error or bias towards the economy or culture, human, progress and social justice in the planning and implementation of policies of the Party and State will negatively affect the implementation of the Party's and State's policies. implementation of the socio-economic development plan in general, as well as for each specific field. Because these goals have a dialectical relationship, there is an interaction in the development process.
\end{abstract}

Keywords: Ho Chi Minh Thought, development, economy, cultural development, people.

DOI: $10.7176 / \mathrm{JPCR} / 54-05$

Publication date:December $31^{\text {st }} 2021$

\section{Preamble}

Ho Chi Minh affirmed that people are the most precious capital, the decisive factor for the success of the revolutionary cause. Ho Chi Minh said: "No matter what is done, it is done by people, and from small to large, from near to far, it's all the same". People are both the goal and the driving force of the revolution. People are the goal of the revolution, so all guidelines, lines and policies of the Party and Government are for the legitimate interests of people, which can be long-term interests, immediate benefits; interests of the whole nation and the interests of sections, classes, classes and individuals. Not every human being becomes a motivator but enlightened and organized people. They must have wisdom and bravery, culture and morality, nurtured on the basis of thousands of years of historical and cultural traditions of the Vietnamese nation... Politics, culture, and spirit are the fundamental driving forces in human motivation. People are the driving force that can only be realized when they operate in an organized manner, with leadership. Therefore, needing the leadership of the Communist Party, Ho Chi Minh clearly affirmed his ideal as "only one desire, the ultimate desire is to make our country completely independent, our people be completely free, everyone has food to eat and clothes to wear, everyone can study". When embarking on the construction of the country, Ho Chi Minh affirmed that the goals and tasks of the Party and State are to "constantly improve the material and spiritual life of the people, first of all, the working people." moving". It can be seen that economic development associated with cultural development in order to improve the material and spiritual life of the people is one of the main content of Ho Chi Minh's ideology. His presentation is very simple and practical, easy to get into people's hearts because it comes from the urgent needs and aspirations of the people, suitable to the conditions of a country from transitional backward agriculture. socialism. Learn and research this problem to clarify the correctness and science in its position and accurately solve it on the basis of dialectics when discussing the relationship between economic development and cultural and human development. of Ho Chi Minh is absolutely necessary in solving the relationship between economic development and cultural and human development in Vietnam today.

\section{Research content}

2.1. Economic development is a premise for cultural and human development, progress and social justice

Ho Chi Minh affirmed: "Growing people" is an objective, urgent and long-term requirement of the revolution. People must be placed at the center of development, both in the country's socio-economic development strategy in the broad sense and in the education and training strategy in the narrow sense...

On the road to socialism, "first of all, socialist people are needed". This should be understood that right from the beginning, it is necessary to set the task of building people with basic qualities, typical for the new socialist human, to set an example and attract society. This is a long process, must constantly improve and improve; is the responsibility of the Party, State, family and each person himself. 
Ho Chi Minh's conception of the new socialist man consists of two closely linked sides. Firstly, inheriting the good values of traditional people. Second, forming new qualities such as: having socialist ideology; have socialist virtues; have wisdom and bravery to master; have a socialist style; benevolent, altruistic, benevolent. The strategy of "planting people" is a focus and an integral part of the socio-economic development strategy.

\subsubsection{Meaning of cultural development, progress and social justice in Ho Chi Minh's economic thought}

The key feature in Ho Chi Minh's economic thought is to constantly improve the material and spiritual life of the people, that the economy must be associated with culture, politics and society. Realizing economic development goals at the same time also aims to realize human development, cultural development, social progress and justice. Therefore, in the process of leading economic construction and development, President Ho Chi Minh always paid attention to the issue of creating a harmonious development between economy, culture and society. According to him, developing culture, realizing social progress and justice is not only the goal of economic development but also an important lever to promote rapid and strong economic development. , more sustainable.

The connotation of the concept of cultural development, progress and social justice is clearly reflected in Ho Chi Minh's thought, which is that everyone can eat well, dress warmly, enjoy happiness and freedom. For Ho Chi Minh, the issue of human liberation and human development is the highest goal that he has always pursued throughout his life. He wished for our country to be completely independent, our people to be completely free, all compatriots to have food, clothing, and education. That is also the aspiration for a society with a highly developed culture, with real justice and equality.

When talking about the goal of socialism that we are building, Ho Chi Minh affirmed that it is a society where no one exploits people, a society in which everyone is completely equal with each other. . He said: "In order to advance to socialism, it is necessary to reform the old society into a new society, a society without the exploitation of man by man, an equal society which means that everyone has to work and have labor rights, those who work a lot enjoy more, those who work little enjoy little, those who do not work get nothing".

Through the above thesis, we can see Ho Chi Minh's very scientific thinking in the concept of equality and social justice. Equity and equality in Ho Chi Minh's concept is not the average, the equalization, but the determination of rights based on the labor ability and dedication of each person.

Development, progress and social justice in Ho Chi Minh's thought are not only a goal but also a driving force for economic development. During his lifetime, he often reminded that development had to be done so that the countryside could catch up with the cities, the mountainous areas to catch up with the lowlands in all aspects, the economy must develop sustainably, and everyone in the country would be happy and satisfied. happiness. That means economic development must always be associated with cultural development and social progress. Therefore, in order to achieve rapid economic growth, the goal of economic development must be harmoniously combined with cultural development and social progress. He pointed out that resources must be used to promote economic development in which cultural development and social progress are an important resource. This is a unique feature of his economic thinking.

From the economic point of view, the realization of social progress and justice is, first of all, a very important and decisive driving force for economic development to increase social labor productivity and improve economic efficiency., technical improvement and improvement in management. Ho Chi Minh affirmed that socialism is fair and reasonable: if you work a lot, you will enjoy a lot, if you work little you will enjoy little, if you don't work, you will not enjoy it. Once social justice has been implemented, employees will clearly realize their rights, responsibilities and obligations towards society, and at the same time show a harmonious relationship between personal interests and those of the society. collective interests. It can be said that the implementation of social justice in economic development is the driving force to promote and bring into full play all the potentials and strengths of individuals and groups in the production process.

\subsubsection{Economic development is a condition for building and developing culture and people}

When analyzing the relationship between economy and culture, Ho Chi Minh noted the equal importance of both issues at the same time, he pointed out that the economy is a component of infrastructure, the foundation of the economy. The construction and development of superstructure. From that point of view, it is necessary to develop the economy in order to create the basis and conditions for promoting and developing culture. He pointed out that culture is a superstructure, the physical and infrastructure facilities of a society have to be built and then culture can be built and have sufficient conditions for development. to improve the material and spiritual life of our people.

Ho Chi Minh always emphasized the need to attach importance to both economics and culture because they have very close interactions with each other. However, he also reminded that equal importance but must have focus, focus, there must be something that goes before and after. In which, the focus must be on the 
economy, prioritizing economic development to achieve an increasingly strong material foundation from which a new culture can be built and developed. He affirmed that the economy is the basis and the decisive factor because after all, if the economy is underdeveloped, stagnant and backward, it is impossible to have a high cultural life. During his life of revolutionary activities, from being a communist soldier to becoming a leader, Ho Chi Minh always cared about people's lives, even though he was busy with hundreds of thousands of jobs, he always Take the time to visit the people. What Ho Chi Minh always cared about, first of all, was the life of the people, from doing business to studying and treating diseases, even about the people's daily meals.

Always affirming the importance of economy to culture, at the same time, Ho Chi Minh also pointed out the role of culture's impact on the economy. This is the dialectical thinking in Ho Chi Minh's point of view. The classics of Marxism have predicted that under a rational regime, which transcends the fragmentation of interests, the spiritual element will naturally belong among the factors of production and will find its place. its position in production. It is with this point of view that President Ho Chi Minh has stated that in the construction of the country, there are four issues that must be paid attention to and of equal importance: politics, economy, culture and society. Nowadays, in the process of perceiving the relationship between economic development and cultural development, we do not always fully grasp these views of Ho Chi Minh, so it is necessary to absolutize our investment. spiritual thinking that ignores economic issues and vice versa.

\subsubsection{Socialist industrialization is the way to bring our people to prosperity and happiness}

Industrialization is an indispensable and objective requirement for all countries in the transition period. Depending on the different conditions and circumstances of each country, industrialization has different contents or purposes, but in general, industrialization is understood as the process of turning an agricultural country into an industrial country. In the condition that "our country is inherently a backward agricultural country", in order to move up to socialism, it is necessary to carry out industrialization, to build a developed industry that plays a key role in the international economy. people. President Ho Chi Minh once said: "Our most important task is to build the material and technical foundation of socialism". In order to advance to communism, to ensure a happy life for the people, it is necessary to industrialize socialism. Ho Chi Minh emphasized that industrialization is the basic way to develop the economy and improve people's living standards. The content of industrialization was mentioned by Ho Chi Minh in the following aspects:

First, develop heavy industry. When talking about the role of heavy industry, President Ho Chi Minh emphasized that "in order to constantly improve people's living standards, to successfully build socialism, we must be determined to develop heavy industry well", "If you want to have more machines, you have to expand the industries of making machines, producing iron, steel, coal, oil... That's the way we have to go: the road to industrialization of the country". The reason why Ho Chi Minh attaches great importance to the development of heavy industry is because of that produce means of production and equip new technologies for the national economy. However, when discussing the development of industry and heavy industry, he did not mention the issue of prioritizing the development of heavy industry. According to Ho Chi Minh, the development of heavy industry must first derive from the requirements in the development of industry and agriculture. If you misunderstand this issue, it is very easy to lead to mistakes in planning development and inefficient investment, especially for a backward agricultural country moving to socialism like ours.

Second, on the development of light industry and handicraft. Ho Chi Minh City is very interested in the development of light industry because "light industry is very closely related to people's daily life... the task of light industry is very important" 1 . Regarding the development of local handicrafts and industries, he advised: "Industries and handicrafts must export many tools for soil preparation, irrigation, transportation... must provide many good and cheap consumer goods for the local population. people".

Third, Ho Chi Minh talked about the content of agricultural and rural industrialization, which is the process of equipping agriculture with machinery, modernizing and electrifying agricultural production. Industrialization in Ho Chi Minh's concept is a long-term process, starting with the most basic area of agriculture and gradually spreading to all aspects of the production process. In order to create conditions to promote the industrialization of agriculture and rural areas, he noted that "industry must develop strongly to provide enough necessary consumer goods for the people, first of all for farmers; provide machinery pumping water, chemical fertilizers, pesticides... to promote agriculture; and gradually supply transplanters and harrows to agricultural cooperatives.".

Fourth, promote scientific and technical development. In the process of building socialism, accompanying the construction of material foundations is the work of research, development and dissemination of science and technology for production. In order to strengthen research and application of science and technology, Ho Chi Minh attaches great importance to improving the qualifications of employees. He advised scientific and technical cadres: "We must make every effort to spread our scientific and technical knowledge widely among the working people, in order to speed up the emulation of more, fast, good and cheap production".

This is a very correct and creative point of Ho Chi Minh. Our country has come up from a backward 
agricultural country, which has just been ravaged by war. What needs to be done in the immediate future is to stabilize people's lives, to provide them with enough food and clothing, then other issues. Agriculture must be developed as a basis and as the main reason: "In order to develop industry, economic development in general must take the development of agriculture as the base and as the main thing. If agriculture is not developed, there is no basis for industrial development because agriculture provides raw materials and food for industry and consumes goods produced by industry.

Through the brief and concise statements of Ho Chi Minh, we can see that the goal of socialist industrialization is to make society more and more progressive, materially increasing, spiritual life increasing day by day. the better, each individual, each person has the conditions to promote their full capacity and forte.

\subsection{Culture is the spiritual foundation of society, promoting sustainable economic and human development 2.2.1. Cultural values, progressive thought and morality are the spiritual foundation of society}

During his life of revolutionary activities, Ho Chi Minh was always interested in cultural issues and he himself laid an important basis for the development of a new culture in our country. His thoughts on building a highly developed culture as a solid spiritual foundation for the whole society are not only expressed through many speeches and articles, but also through his own activities. His practice. In his definition of culture, Ho Chi Minh pointed out that: human beings for the sake of survival as well as the purpose of life create language, writing, morality, law, etc.. of him was introduced right from the 40s of the last century. Accordingly, culture is associated with the reason for existence and the purpose of human life. Culture is the totality of human creations and it not only meets spiritual needs, but also meets human material needs.

That perception of Ho Chi Minh helps us understand that culture is not just a form of entertainment, a spice, nor does it allow to consider culture as the tail of political and economic activities. Ho Chi Minh once said that a nation can be oppressed, exploited, and materially exhausted, but the vitality of that nation remains, and just waiting for the right opportunity, that nation will rise up. That vitality is cultural values, good cultural traditions. The history of thousands of years of our nation's struggle to build the country has proven that. Thus, traditional cultural values are the source of the life of a nation. It is the spiritual foundation of the whole society, the "principle" of a nation. It helps to unite members of society, creating internal strength for each country in the development process.

\subsubsection{Developing education and training to promote economic development and human development.}

In Ho Chi Minh's concept, man is the sum total of social relations from narrow to wide. Ho Chi Minh never considers people in an abstract way, but always comes from the situation of concrete real people in social relations with many different aspects and dimensions. It can be affirmed: Ho Chi Minh's most basic approach is still to put people in relationship with the ethnic community. Humans are a unified whole between biological factors and social factors. Therefore, Ho Chi Minh always believed that man, in his personality structure, is a system that includes the synthesis of many components such as: body and soul, physical strength and intelligence, the creature and the other. society..." Every human being has good and evil in their hearts. We must know how to make the good part in each person bloom like a spring flower and the bad part fade away, that's the revolutionary attitude. For those who have bad habits, except those who rebel against the Fatherland and the people, we must also help them make progress by making the good part in people flourish to repel the evil part, not the evil part. This way of thinking allowed Ho Chi Minh to reach a comprehensive view of the human being, which was the basis for him to understand, sympathize and worry about people.

According to Ho Chi Minh, the struggle for national liberation, national reunification, building a new life, moving towards socialism must all start with human capital, from promoting the human factor. At the same time, the role of the masses is very important, he wrote: "The people are very clever, very enthusiastic, very heroic. Therefore, we must study the people, ask the people, understand the people. the people... the people agree, anything can be done. The people don't support it". Culture is a broad category, including many fields, each with different roles in social development. Education and training in Ho Chi Minh's thought plays a role in creating strength and wisdom for Vietnamese culture, contributing to the development of society. Very well aware of the great role of education and training, since 1918, in the Declaration of the Annamese People's Claim sent to the Versailles Peace Conference, Ho Chi Minh asked for "Freedom of study, success establish professional technical schools in all provinces for the natives". This was a completely new problem for the Vietnamese people at that time.

With a vision of the times and a development mindset, Ho Chi Minh was aware of the problem "for the sake of ten years, one must plant trees, for the benefit of one hundred years, one must plant people", so in his opinion, the teacher Education plays a very important role. Developing education is a fundamental and inseparable task of the Vietnamese revolution. Right from the early days of joining the revolution, Ho Chi Minh criticized the reactionary nature of the colonial education, criticized the stupid policy that the French government had implemented in Vietnam. After the founding of the Party, he called for the immediate practice 
of "education of the whole people", that is, universal education. After the success of the August Revolution, after regaining our independence, all the strength and will of our people from the goal of fighting for independence and freedom was turned to the struggle for the goal of prosperity and happiness. because as Ho Chi Minh once said: "We fight for freedom and independence, but the people die of hunger and cold, then freedom and independence will do nothing. People only know the value of freedom and independence. It was established when the people were well fed and clothed".

Ho Chi Minh said: "All lines, mottos, policies ... of the Party are only aimed at improving people's lives". Developing production, improving people's lives, that is the goal, and also a measure of the correctness, meaning and value of each of our economic policies and measures. According to him, "socialism is to make the people rich and the country strong", therefore, it is necessary to boost production and develop the economy "to make the poor enough to eat. Those who have enough to eat are quite rich. People who are quite rich get richer."

Thus, in Ho Chi Minh, the view of goals is consistent with the view of motivation, because the economic purpose is to serve the people, so it must rely on the people, know how to promote human strength, physical strength, work spirit. owner of the people to make production develop. He said: "Our Party and State use the force of the people to build an increasingly happy life for the people. That is socialism." Thus, the people are the source and both the goal and the driving force of the economy. The leader of the entire Party and the people abolished the old education system and built a new education. That is Ho Chi Minh's profound awareness of the need to develop education because education and training are an integral part of the cause of economic construction, cultural development and human development.

The goal of education and training in Ho Chi Minh's concept is to "train them to become useful citizens for Vietnam... to develop comprehensively human beings, and to fully promote their available capacities. of the children"1; is "learning to work, to be a person, to be an official. Learning to serve the union, class and people, the Fatherland and humanity". Thus, education is not to create "bookcases" but does nothing. The most important issue of education is to be associated with life, to answer the questions that practice is asking. Failing to do that, it is inevitable that not only Vietnam's education will fall behind, but also the whole country of Vietnam will not be able to develop, unable to step up to the glory station, standing shoulder to shoulder with the powers of the five continents.

According to Ho Chi Minh, education is not only the transmission of good but also must point out the limitations of people, distill and absorb the cultural quintessence of humanity. In many of his writings, Ho Chi Minh pointed out the limitations of people and Vietnamese traditions in general, from which to draw lessons from experience, and find ways to correct these shortcomings. is a development value of education. Ho Chi Minh affirmed that education will help people have capital in the history and culture of the nation and the world, thereby actively participating in and preserving, building and defending the country. Education will help each citizen have the knowledge to "turn an ignorant, miserable country into a country of high culture and happy life". To achieve that goal, education must be comprehensive. That content includes culture, professional expertise, national defense and security, politics, ethics, etc.. Ho Chi Minh emphasized: "The minds of young people are as pure as a white silk, dyed green is become green, dyed red will become red, so studying at school has a great influence on the future of young people and the future of young people is the future of the country"; must foster a spirit of learning and progress because ignorance is foolish, foolishness is cowardly; no education, no cadres, let alone the economy, education is an important front. He said: "without education, without cadres, there is nothing to say about cultural economy". Education contributes to the construction of the future of the country, effectively contributes to the construction and defense of the socialist fatherland, education and training is an indispensable tool for human liberation and human development. free and all-rounder.

\subsubsection{The mass media with the construction of a healthy social spiritual life}

During his lifetime, President Ho Chi Minh did not directly use the concept of "mass media", but its content was mentioned many times in many of his speeches and articles. People often use words such as press, radio; literature, art, etc., with the same meaning as the mass media. However, Ho Chi Minh not only defined the function and task of providing and transporting information, but he also pointed out the great significance of the press, arts, etc., in the development of social culture, building construction. building a progressive and healthy spiritual life among the people. The press, literature and art of any period, too, are a part of ideological work, closely related to the general requirements and tasks of the revolution. Our Party has emphasized that the press must play an important role in protecting and developing Marxism-Leninism, Ho Chi Minh's thought, viewpoints and lines of the Party, the working class, and social ideals. ideology, good values in the nation's cultural traditions, and the quintessence of world culture, occupy a dominant position in the spiritual life of society. This point of view of the Party represents the correct and creative application of Ho Chi Minh's thought in the new era. Ho Chi Minh pointed out that journalists must consider their pen "a sharp weapon in the cause of supporting the main cause of exorcism". Thus, Ho Chi Minh believed that the press must not only 
praise the good and set good examples, but also have to fight the bad. Journalists must see that besides the positive achievements of the revolution, besides the examples of good people and good deeds, there are still existing bad habits such as bureaucracy, corruption, wastefulness, socialism. individualism, narrowmindedness, etc.., from which to discover and celebrate the good, and fight to contribute to repelling the bad. However, that struggle is not always easy, journalists must have a firm ideological stance, distinguish between friend and foe, then write correctly and accurately. President Ho Chi Minh pointed out: "Writing to highlight the good and bad things of our people, our soldiers, our officers, and our friends. At the same time to criticize our own shortcomings, those of cadres, the people, and the army. Do not write only the good, but hide the bad. But criticism must be right. If the good, the good, it must be in moderation, not exaggerated. How have said the same. Our soldiers and people also have enough good things to mention, there is no need to fabricate them."

Not only interested in journalism, President Ho Chi Minh also paid great attention to the construction and development of literature and art. Referring to Ho Chi Minh's thought on culture and art is also talking about the idea of "art and culture is a front". The artistic front had no sword and no gun, but it was a front that had a great and lasting impact on the revolutionary cause. "Literature has the power of a thousand troops", "literature beautifies the country". According to Ho Chi Minh, Vietnamese revolutionary literature has the effect of sowing seeds of liberation, promoting the spirit and resistance forces, "honestly praising new people, new things... not only to set an example." model for us today, but also to educate our children in the future", and at the same time "severely criticize bad habits... in order to make our society healthier and better". If there is a cultural and artistic front, there must be soldiers fighting on that front. Writer-soldier, artist-soldier is a noble title that Uncle Ho bestows upon people who do arts and crafts. Artists and writers are soldiers who follow the revolutionary path of the working class, serving the people, first of all, the working people. According to Ho Chi Minh, the masses of the people are the root of the country, the owner of the revolutionary cause, so the arts must take the happiness of the compatriots and the nation as the basis. When asking the question: Writing for whom? Writing for what? What purpose does writing serve? He said: "In terms of composing, it is necessary to understand, relate and go deeply into the people's lives. In this way, we can express the heroic and resolute spirit of our army and people, and at the same time to help develop and enhance that spirit". Literature and art cannot be for a certain purpose, but must be closely related to politics - economy, must be in economy - politics. Literature and art must know how to fight for truth, goodness and beauty; at the same time must fight the false, the evil, the bad.

\subsubsection{Building cultural institutions to strengthen the Party's leadership role and the State's management}

Currently, there are many views that the leadership of the Party and management of the State in general are matters of purely political significance. Such a concept does not accurately reflect objective reality, does not see the interwoven and mutually dominant relationships among economic, cultural, political, ideological and spiritual aspects. In his opinion, Ho Chi Minh correctly acknowledged and evaluated the dialectical unity among those aspects. According to him, "widely understood culture is also political, deeply understood politics is also culture". From the perspective of the above integrative thinking, it can be seen that the construction and assurance of the leadership of the Party and the management of the State has been considered by Ho Chi Minh in the depth of culture and has reached the core values of the Party. sustainable core. Accordingly, in order to build a "advanced and imbued with national identity" Vietnamese culture, it is necessary to focus on improving the cultural life in every village and facility through proper and adequate attention to the issue of building cultural institutions to enhance the leadership of the Party and the management of the State. This is a key and decisive issue in the cultural fields because in any era, any social regime needs cultural institutions to transmit the official culture of the State to the people. people from all walks of life, and at the same time organize cultural activities in accordance with the requirements of standards, ethics, lifestyles and customs of that era. Cultural institutions can be understood as the cultural whole that fully converges the following factors: physical facilities; organizational apparatus, personnel; regulations on cultural activities. The process of building and consolidating the system of cultural institutions should focus on the following main issues:

Firstly, to build mechanisms and policies of the Party and the State. According to Ho Chi Minh, all policies of the Party and State must aim at the goal of gradually improving the people's material and spiritual life. In the process of leading the construction of socialism, besides economic policies, Ho Chi Minh attaches great importance to socio-cultural development policies. Cultural policies must always aim at achieving social stability and development, bringing happiness to people. According to him, making the right policies and implementing them effectively will become a great driving force, uniting the whole nation, stably stabilizing society, bringing into full play all material and spiritual potentials. gods and creative talents of all classes of people. The results of those social policies will also be a solid basis to prevent and frustrate all anti-imperialist and reactionary plots and tricks. He affirmed that our Party and State come from the people, being both the leader and the servant of the people, with no other interests other than the people's interests. Therefore, "The policy of the Party and the Government is to take great care of the people's lives". 
Second, build a system of facilities to serve cultural activities. As a very important element of cultural institutions, the system of facilities serving cultural activities has always been built by Ho Chi Minh and our Party. In the process of leading the construction of a new culture, Ho Chi Minh affirmed that he must know how to absorb traditional cultural values, but that does not mean keeping the traditional cultural elements intact, but having to choose and promote the traditional cultural values. progressive, suitable for the new era, because in the reality of national life, there are values that are appropriate for one period but not in another period. The traditional values that the new culture must inherit from Ho Chi Minh mentioned the tangible cultural heritages in which he emphasized the historical and cultural relics. In the past, communal houses, pagodas, and shrines on the one hand met the people's cultural, religious, and religious needs; On the other hand, it is also a place for cultural activities such as festivals, folklore activities, community exchanges. It is necessary to preserve traditional cultural values to pass on to the next generations. In order to preserve cultural relics throughout the country, right after 3 months after taking power, President Ho Chi Minh signed Decree No. 65-SL laying the first basis for preserving cultural properties. national culture and pass it on to generations to come. In addition, he also directed localities to build cultural and sports venues to serve the current needs and new requirements of the people's culture and spirit. The more civilized the society, the higher the human enjoyment needs, so the more important the role of the cultural infrastructure system is, both as a place for cultural and spiritual activities of the community, and as a place to hold the position of the community. A key position in organizing propaganda activities in service of political and social tasks, as well as meeting the people's demand for cultural enjoyment and creativity, contributing to preserving and promoting cultural identity. nationalization

Third, build a contingent of staff doing cultural work. Along with perfecting mechanisms and policies of the Party and State; When building material foundations for cultural activities, Ho Chi Minh also regularly takes care of building a contingent of staff working in the field of culture. People are very clearly aware that "The cadre is the chain of the apparatus. If the line is not good or not running, the engine, even if it is good, even if it runs the whole machine, will be paralyzed. Officers are the ones who bring the policies of the company. The government and the Unions implement it among the people. If the cadres are bad, good policies cannot be implemented. Considering culture as an important front, Ho Chi Minh called culture cadres as cultural soldiers, art soldiers and in order to carry out their tasks, he affirmed that cultural soldiers first. "It is necessary to have a firm stance and the right mindset". President Ho Chi Minh pointed out that cultural cadres in particular as well as all our cadres in general must train in ideology, politics, the will to strive and a sense of responsibility. The reason why it is necessary to have the right stance and strong ideology is because only standing firmly on the position of the working class, following the revolutionary line of the Party and the working class, and equipped with Marxist-Leninist ideology can it be reflected. truth, access to the truth. In order to have a team of truly capable cadres, Ho Chi Minh has painstakingly built and established a system of cadre standards including virtue and talent, in which virtue is the root that determines sustainable development. staff stability.

\subsection{People are the goal and the driving force of economic, cultural and sustainable development}

To implement the strategy of "growing people", many measures are needed, but education and training are the most important measures. Because, good education will create goodness and bring bright future for young people. On the contrary, bad education will adversely affect young people. Educational content and methods must be comprehensive, including virtue, intelligence, body, and beauty; must put the morality, ideals and revolutionary sentiments and socialist lifestyle first. "Growing people" is a "hundred-year" job, can't be rushed "one-on-one", "learning never ends, while we live we have to learn".

\subsubsection{The goal of human liberation is always associated with the goal of national liberation and class liberation}

Ho Chi Minh's philosophy about human beings is rooted in the reality of life with daily needs and interests, always longing for freedom and happiness, being awakened to liberate oneself, to fight for freedom. own cause and happiness. That is the noble philosophy of life in Ho Chi Minh's conception, towards action for people, for people. The word "person" in Ho Chi Minh's concept is expressed as a complex, both an individual person and a social community from family to class, nation to humanity in general. But regardless of the meaning, Ho Chi Minh has always recognized that people have a great and decisive role in all creative activities that create social life, civilization, progress and development. It is also from the absolute belief in people that all his life, President Ho Chi Minh has always strived for the goal of human liberation and that goal has always been closely linked with the goal of national liberation, liberation of grant. Human liberation is not only about freeing people from oppression, exploitation, and injustice, allowing people to enjoy freedom and happiness, but liberating people must also free people from all forgiveness. in order to develop the best human nature. That liberation is not a gift brought to man from somewhere, but must be carried out by man himself, the cause of man himself. 
Going out to find a way to save the country, clearly understanding the people's aspiration for independence and freedom. Ho Chi Minh had faith in the people's perseverance and insurrection when it was launched. Commenter: "It is wrong to say that Indochina consists of twenty million exploited people, now ripe for revolution, but to say that Indochina does not want to make a revolution and is satisfied with the current regime like the Our masters are still thinking the same thing, it's even more wrong... Behind the negative submission, the Indochinese hides something that is boiling, screaming, and will explode violently, when The time has come". From the above correct perception, he understood that as long as there is a right path, a suitable method of conducting the revolution, the people's force will become a great power: "Ooppression and exploitation The inhuman exploitation of the French Empire has made our compatriots understand that the revolution is alive, without the revolution is dead - that's why the revolutionary movement is growing stronger and stronger.

The people's democratic national revolution according to Ho Chi Minh's concept actually consists of two revolutions: the national liberation revolution in order to abolish the colonial and imperialist domination; and democratic revolution to abolish feudalism and bring democracy to the people. Thus, in the people's democratic national revolution, the issues of national liberation, class liberation and human liberation were closely linked. The socialist revolution is aimed at consolidating the independence of the nation, developing the country to create conditions for higher democratic development, and realizing more radical human liberation. That right revolutionary way of Ho Chi Minh quickly penetrated into all social strata, thereby leading to great and glorious victories for the whole nation. In revolutionary leadership, President Ho Chi Minh for the people and promote the people, considers everything to be the people as the root, "what is beneficial for the people must be done with all their might, whatever is harmful to the people must be stopped." avoidance". He always advised the Party and the government to pay attention to the people's lives, to take care of and foster the people's strength. Independence for the nation, freedom and happiness for the people is the striving direction of the entire Party and people. Gaining independence is difficult, but maintaining it is not easy. As for building a rich and strong country, building a socialist regime according to Ho Chi Minh's words, it is a giant battle, it must be the cause of the entire people. Ho Chi Minh always associated national liberation with human liberation, national independence with freedom and happiness of the people. That became his ambition during his life of revolutionary activities that he always pursued. In a situation where the country is still at war, and the issue of freedom and happiness of the people has only been resolved to a certain extent, under the socialist regime, this issue must be fully resolved. than. Ho Chi Minh believes that the people can only see the true meaning and value of socialism when the issue of their freedom and happiness is fundamentally resolved. He pointed out that if the country is independent but the people do not enjoy freedom and happiness, then that independence has no meaning. Thus, according to Ho Chi Minh, the real purpose of national independence and socialism is national liberation, social liberation in order to liberate people.

\subsubsection{A developed, progressive and sustainable society is a society where people are free, equal and happy}

The reality of the Vietnamese revolution has proved that the Vietnamese people, under the leadership and guidance of the Party and Ho Chi Minh, have become a decisive factor and a driving force in promoting social development and progress. Moreover, people are not only the driving force but also the highest goal, the goal towards development and social progress. President Ho Chi Minh affirmed that we do the revolution to liberate the nation, liberate people and develop people, raise people to a new height, worthy of being the subject of all development processes in the world. socialist new society. Therefore, comprehensive human development must first ensure human freedom, equality and happiness. This is a very important thought with profound humanistic meaning of Ho Chi Minh. Marxism-Leninism together with the light of the October Revolution helped Ho Chi Minh determine the next goal of the revolution, which is not only national independence but also socialism, because only the Only then will people be completely liberated, and only socialism will bring true freedom, equality and happiness to all people. In 1945, when reading the Declaration of Independence giving birth to the Democratic Republic of Vietnam, President Ho Chi Minh quoted important passages in the Declaration of Independence of the United States and in the Declaration of the Rights of Man and of the Citizen. of France. Accordingly: "All men are created equal. They are endowed by their Creator with certain inalienable rights, among which are the rights to life, liberty, and the pursuit of happiness", and "man is born free and equal in rights, and must always be free and equal in rights".

Those noble slogans of freedom - equality - charity of the bourgeoisie have such great appeal that thanks to this, the bourgeoisie has drawn the vast majority of the population to its side in the process. The bourgeois revolution overthrew the feudal system. However, after taking power, the bourgeoisie showed a reactionary face, taking advantage of the flag of freedom, equality and charity to exploit the proletariat and the colonial peoples. Ho Chi Minh compared colonialism to a two-pronged leech. They enslave, deprive the colonists of all minimal rights, and oppress the people in the capitalist countries themselves. The capitalist system replaced feudalism, but not everywhere people are happy, even though the capitalist society is modern, the situation of 
the working people is still miserable, still being oppressed and exploited.

From the above perception, Ho Chi Minh affirmed that there cannot be freedom - equality - charity for all people in a capitalist society. To completely liberate people and develop human beings, the only way is to advance to socialism. A socialist society with a high level of development will completely eliminate the exploitation of people, and create conditions for people to develop comprehensively both physically and mentally. Ho Chi Minh wrote: "There is no regime that respects the person, pays attention to the correct personal interests and ensures that they are satisfied by the socialist and communist regimes".

A new society according to Ho Chi Minh's concept must be a society in which people are completely free, completely equal and happy. Humans have comprehensive development in culture, morality and intelligence. Therefore, Ho Chi Minh believes that socialism is the ideal society, not only in democracy, in a developed economy, in modern science and technology, but also in the deeply humane values of Vietnamese culture. ethics - ethics. In his opinion, Ho Chi Minh always affirmed that "if you want to be socialist, you must have: a socialist. To have a socialist, you must have socialist thought", that means is that human development must be put together with economic and cultural development; may even be developed earlier than economic and cultural development. Building comprehensive human development is not only improving material life but also fostering thought, spirit, emotion, culture, expertise, etc.. He said: "The Socialist State and people's democracy only cares about benefiting the people, first of all, the working people, making progress in material and spiritual terms, so that no one exploits people in society. The unique feature of Ho Chi Minh's concept is that he recognized very early on that economic development must go hand in hand with cultural development; economic development in order to achieve the construction of modern technical infrastructure as the foundation for social development; Cultural development includes broad content such as ethics, customs, practices, personality, lifestyle, etc., thereby improving people's quality of life. Economic development without paying attention to culture will not achieve sustainable development. This means that the goal of building a comprehensive human development can be achieved.

\subsubsection{Cultural activities must be closely associated with political, economic and social activities to form a development resource}

Culture has a close relationship with other aspects of social life such as economy, politics, etc. According to Ho Chi Minh, he wants to win in the process of building socialism and improving people's living standards. People both materially and spiritually need to focus on all four issues of economy, politics, culture and society - these are the four basic aspects of social life. In the process of development, these four aspects have an interaction with each other, so if you know how to combine activities on the economic, political, cultural and social aspects together, they will form a resource. great for general development. Cultural activities must be associated with economy because economics is the foundation of social culture, the process of building and developing culture cannot be separated from the process of economic development. economic development. On the contrary, the economy cannot develop by itself without a cultural foundation, culture is not passively dependent on the economy. Associating cultural activities with economic development is a guarantee for harmonious and sustainable development. Economic development means that people's material life is guaranteed, thereby realizing the people's cultural development goals. The socialist revolution is a long-term revolution, in order to successfully realize the goals of the socialist revolution, we need to fight, build and develop in many aspects of the socialist revolution. social life, in which culture is a strategically significant front. Victory on the cultural front is a condition, creating a spiritual foundation for the construction and development of social life.

Culture must be in politics and must serve the political task. When politics is liberated, culture is liberated. Liberation politics paved the way for cultural development. Ho Chi Minh outlined the way to conduct a political revolution first, specifically the national liberation revolution to gain power, thereby liberating culture, paving the way for culture to develop. Under the leadership of politics, culture must participate in political tasks, participate in revolution, resistance war and build socialism. The front nature of culture is not only against foreign invaders, but also against foreign invaders. had to fight against the internal invaders. Therefore, culture needs to have the courage to seriously criticize bad habits such as embezzlement, corruption, wastefulness, laziness, bureaucracy, etc. Westerners used to wonder: Why was Ho's political line so easily accepted and responded to by the whole nation? Only later, when the war of invasion of Vietnam by the imperialists was over, people understood that: Ho Chi Minh's political line was always imbued with cultural spirit. In other words, Ho Chi Minh's thought affects society as a cultural force, a force of rational and emotional unity, generality and simplicity, persuasion by persuasion etc.. manifests itself to the first level. Ho Chi Minh's culture and thought penetrated into society, affecting the way of thinking and living of tens of millions of people, community relations and personal cultivation. 


\subsubsection{Promote the basic motivations: traditional values, education, wisdom, democracy.}

The value and depth of Ho Chi Minh's conception lies in recognizing and properly assessing the role of basic human motivations in the process of social development. These dynamics can be considered through traditional, intellectual, democratic and ethical values, because they are all constitutive elements of the spiritual life of people and society. It reflects the relationships between people and people, people with society; reflects the level of awareness in human activities. Promoting the basic spiritual - political motivations according to Ho Chi Minh's thought is first of all to bring into full play the human factor - which is both the driving force and the ultimate and highest goal of all development processes. develop. Right from the early years of revolutionary activities, Ho Chi Minh clearly pointed out the role of traditional national values in the Vietnamese revolution. He asserted: "Now, nothing can be done for the Annamites unless it is based on the great and unique motives of their social life". Ho Chi Minh said that one of the reasons for the victory of the revolution was to build a great national unity bloc on the basis of promoting traditional values of which patriotism is a key feature: "Patriotism as well as precious things. Sometimes it is displayed in a glass case, in a crystal vase, clearly visible. But sometimes hidden in a chest, in a chest. It is our duty to make precious things. The secret is all put on display." The traditional values that make up the source of Vietnam's spiritual strength were highly promoted in the Ho Chi Minh era.

Intelligence and education are also one of the great motivations for each individual as well as for the development of the whole society. Only on the basis of an intellectual and ethical culture can people really promote their qualities and abilities effectively. Because of that, right from the early days of the government's establishment, Ho Chi Minh called for the launch of a movement to eradicate the ignorant because ignorance is as dangerous as foreign invaders. Appreciating the role of intellectual motivation, Ho Chi Minh's ethics emphasized the role of education and considered it as a basic strategy in national construction and development. If you want to build a country, you must have education. It is necessary to learn culture, politics, technology. It is necessary to learn theory in combination with struggle and daily work... Learning goes hand in hand with action.

Ho Chi Minh considers democracy also a very important driving force. Democracy according to Ho Chi Minh is the essence of the new regime, so his first concern is "practicing democracy so that everyone can enjoy democratic rights and freedoms". Ho Chi Minh pointed out the specific content of democracy in the fields of politics, economy, culture, society, ideology and asked how to truly expand democracy, to the people know how to use democracy and have the capacity to master. In order for democracy to truly become a powerful driving force, Ho Chi Minh asked: on the one hand, to develop democracy to the fullest extent, to bring democratic values to the masses in order to bring into play the highest intelligence and capacity. endlessly of all classes of people. He said: "Practice democracy is a universal locking spoon that can solve all difficulties", "only when democracy is brought into full play, only all forces of the people can be mobilized to move the revolution forward". . On the other hand, we must fight against all manifestations of democracy violations such as authoritarianism, autocracy, and bureaucracy. In the process of using and promoting the system of cultural, political and spiritual dynamics for development, Ho Chi Minh also paid great attention to the timely detection and remedial of counter-motive factors. This is considered as two sides of a dialectical process in Ho Chi Minh's conception. The factors that inhibit the development and destroy the motivations according to Ho Chi Minh can be divided into two groups. One type is the old society's outdated ideas, practices and habits that still exist. One is lagging, incompetent; the revolutionary moral weakness of cadres and party members and the mistakes and shortcomings made; enemy resistance. Both types need to be phased out in the process of building a new society.

\section{Conclusion}

From a very early age, President Ho Chi Minh was interested in the relationship between the constituent elements of the national economy. He gave his opinion on the structure of almost all levels, branches and economic fields: from the economic structure of the whole country to the economic structure of each industry, the structure of the region (plain, midland, mountainous and coastal areas), the structure of the central economy and the local economy, the domestic economy and economic cooperation with foreign countries - that is, the relationship between export and import, between self-reliance and taking advantage of resources. cooperation with foreign countries.

Ho Chi Minh also pointed out that since the starting point of our ascent is agriculture, in the immediate future we have to take agriculture as the main thing, that is, according to the agro-industrial structure. But agriculture can only thrive and have abundant products when we use machines to produce widely, but if we want to have many machines, "we have to expand the industries of making machines, making iron." , steel, coal, oil... socialist industrialization is still the common goal of our people's striving, and the path to true prosperity of our people. Not only agriculture and industry, President Ho Chi Minh also attaches great importance to the role of circulation of goods and commerce in promoting production and development, 
considering this as a basic part of the structure of transportation. movement of the economy. He said: "It is important to understand that in the national economy there are three important aspects: agriculture, industry, and commerce. The three aspects of work are closely related to each other... If the trade link is broken, it is not related. If agriculture and industry can't be linked, it won't be able to consolidate the union of workers and farmers. If trade does not run, agricultural and industrial activities will be fragmented."

President Ho Chi Minh's economic thought on the structure of the national economic sectors in the transition period shows a cross-cutting point of view: Focusing on agricultural development in the relationship of dialectical impact on development. industry through the expansion of production and circulation of goods, paying great attention to food production and harmonizing it with the production of food, consumer goods and export production in order to take advantage of domestic comparative advantage and take advantage of foreign factors to promote the development of the domestic economy. For the local economy, it is also important to focus on the strengths of each locality and region for development to ensure the principle of efficiency. The economic attachment to politics, society, culture and human morality is one of the very basic views of Ho Chi Minh's economic thought. Politics directs the economy, economic development will strengthen the sustainable political foundation. But economic development can also lead to disruption, causing imbalance between economy and culture, economy and social progress - morality, economy and natural environment, etc. Ho Chi Minh is very sensitive to these issues, so in directing economic development, he not only spoke on one hand, emphasized one-way, but always had a combination, in order to create a harmonious development between the economy and the world. with social progress and human morality. Ho Chi Minh pointed out that in the process of national construction, four political, economic, cultural and social issues must be paid equal attention and importance, of which "culture must practically serve the people, contribute to contributing to improving the happy and healthy life of the masses..., cultural content must have educational significance... Culture must be associated with labor and production". According to him: "Culture, art, like all other activities, cannot be left out, but must be in the economy and politics".

President Ho Chi Minh was very aware: strengthening cultural construction is to perform the basic task of economic development. The economic development of the country depends greatly on the construction of culture to create a strong spiritual motivation. The people wrote: "Improving the people's cultural level will help us accelerate the economic recovery and democratic development... also a necessary thing to build our country into a peaceful and unified country. , independence, democracy and wealth". At the same time, also from his point of view, on the one hand, economic development is the foundation for building culture, but on the other hand, culture has its relative independence. Culture does not depend mechanically on material living conditions and living standards, but sometimes the ideological-cultural revolution must be one step ahead to pave the way for the industrial revolution, in the spirit of culture. light the way for the nation.

Entering the construction of socialism, production becomes the most important political task, so that all serve production. At the same time, he also said that each person should clearly realize: "Work is a sacred duty of every citizen towards the Fatherland. Everyone must voluntarily participate in labor according to their ability and voluntarily participate in labor, contributing construction of the country". According to Ho Chi Minh, contributing to the development of production must become a measure of each person's morality and revolutionary will, and he asked to "resolutely fight against the disease of idle talk, ostentatious formalism, and unethical working style. aimed at increasing production". Along with that, President Ho Chi Minh had a view to raise the collective spirit and fight against individualism, however, he said: "If those individual interests are not contrary to the interests of the collective, then they are not. must be bad, ... The collective interests of the collective are guaranteed by the private interests of the individuals to have the conditions to be satisfied".

Thereby, we see that Ho Chi Minh paid great attention to the role of the beneficial factor in the economy, and at the same time always took the morality of the collective owner to promptly adjust conflicts of interest, creating a combination harmonize public interests and private interests, so that the state, cooperatives and cooperative members all benefit. Ho Chi Minh's thought on the dialectical relationship between economic development, cultural development and people is the model of creative application of fundamental principles.

Marxism-Leninism and the laws of economic and cultural development on the specific historical conditions of Vietnam. Today, conditions in the country and in the world have undergone profound changes, but his views on economic development associated with cultural development remain current. In the current period, Ho Chi Minh's thought on the relationship between economic development, culture and human development is really the ideological and theoretical foundation for our Party to plan the construction , economic and cultural development, improvement of people's material and spiritual life. That thought includes a system of basic views: Economic development is a premise for cultural and human development, progress and social justice; Culture is the spiritual foundation of society and sustainable development. People are the goal, the driving force of economic, cultural and sustainable development.

The views of President Ho Chi Minh on the relationship between economic development and cultural and human development lay the theoretical basis for setting goals for sustainable development and are the basic 
orientation for the development of sustainable development. resolve the relationship between economic development, cultural development and human development in Vietnam in the current period.

\section{REFERENCES}

1. Pham Ngoc Anh (Ed, 2010), Ho Chi Minh Thought on Party culture, National Political Publishing House, Hanoi.

2. Pham Ngoc Anh \& Bui Dinh Phong (2009), Ho Chi Minh City culture and development, Political Administrative Publishing House, Hanoi.

3. Thanh Duy (2010), Ho Chi Minh's humanism in the heart of the Vietnamese nation, Social Science Publishing House, Hanoi.

4. Pham Duy Duc (Ed, 2010), Developing Vietnamese culture in the period 2011 - 2020 with methodological issues, National Political Publishing House, Hanoi.

5. Dang Xuan Ky (Ed, 2005), Ho Chi Minh Thought on cultural and human development", National Political Publishing House, Hanoi.

6. Dinh Xuan Lam \& Bui Dinh Phong (2007), Culture and development philosophy in Ho Chi Minh Thought, National Political Publishing House, Hanoi.

7. Ngo Van Luong (2010), Ho Chi Minh Thought on the Economy, National Political Publishing House, Hanoi.

8. Ho Chi Minh (2011), Complete Volume, Volume 1, National Political Publishing House, Hanoi.

9. Ho Chi Minh (2011), Complete Volume, Volume 2, National Political Publishing House, Hanoi.

10. Ho Chi Minh (2011), Complete Volume, Volume 3, National Political Publishing House, Hanoi.

11. Ho Chi Minh (2011), Complete Volume, Volume 4, National Political Publishing House, Hanoi.

12. Ho Chi Minh (2011), Complete Volume, Volume 5, National Political Publishing House, Hanoi.

13. Ho Chi Minh, Complete Volume, Volume 6, National Political Publishing House, Hanoi, 2011.

14. Ho Chi Minh (2011), Complete Volume, Volume 7, National Political Publishing House, Hanoi.

15. Ho Chi Minh (2011), Complete Volume, Volume 8, National Political Publishing House, Hanoi.

16. Ho Chi Minh (2011), Complete Volume, Volume 9, National Political Publishing House, Hanoi.

17. Ho Chi Minh (2011), Complete Volume, Volume 10, National Political Publishing House, Hanoi.

18. Ho Chi Minh (2011), Complete Volume, Volume 11, National Political Publishing House, Hanoi.

19. Ho Chi Minh (2011), Complete Volume, Volume 12, National Political Publishing House, Hanoi.

20. Ho Chi Minh (2011), Complete Volume, Volume 13, National Political Publishing House, Hanoi.

21. Ho Chi Minh (2011), Complete Volume, Volume 14, National Political Publishing House, Hanoi.

22. Ho Chi Minh (2011), Complete Volume, Volume 15, National Political Publishing House, Hanoi.

23. Bui Dinh Phong (2010), Ho Chi Minh's philosophy on Vietnam's development, Youth Publishing House, Hanoi.

24. Song Thanh (2010), Ho Chi Minh outstanding cultural house, National Political Publishing House, Hanoi.

25. Nguyen Chi Trung (2010), Some current economic and political issues, National Political Publishing House, Hanoi. 